\title{
Spatial and temporal variability in Phormidium mats and associated anatoxin-a and homoanatoxin-a in two New Zealand rivers
}

\author{
Mark W. Heath ${ }^{1, *}$, Susanna A. Wood ${ }^{2}$, Ken G. Ryan ${ }^{1}$ \\ ${ }^{1}$ School of Biological Sciences, Victoria University of Wellington, PO Box 600, Wellington 6140, New Zealand \\ ${ }^{2}$ Cawthron Institute, Private Bag 2, Nelson 7001, New Zealand
}

\begin{abstract}
Toxic benthic cyanobacterial proliferations in freshwater are becoming increasingly prevalent, and associated animal poisonings are being reported with greater regularity. Despite this, few studies have investigated spatial and temporal variations in freshwater mat-forming Cyanobacteria and their associated toxin production. Some sections of the Hutt and Wainuiomata rivers (lower North Island, New Zealand) contain extensive Phormidium sp. proliferations that sometimes produce anatoxin-a (ATX) and homoanatoxin-a (HTX). The percentage coverage of Phormidium sp., ATX and/or HTX concentrations and a suite of physicochemical parameters were monitored at 8 sites for 12 mo. The percentage coverage of Phormidium mats was greater in the summer months and these correlated with warmer water temperatures and stable river flows. Flows in excess of 3 times the mean resulted in the removal of Phormidium mats. There was no correlation between the presence/absence of Phormidium mats and water-soluble nutrients. The presence and concentration of ATX and/or HTX and their degradation products, dihydroanatoxin-a and dihydrohomoanatoxin-a, was highly variable across all sites and over time. Anatoxin-a and HTX occurrence was restricted to periods of warm water temperatures (above $13.4^{\circ} \mathrm{C}$ ) and below average river flows.
\end{abstract}

KEY WORDS: Anatoxin · Benthic Cyanobacteria $\cdot$ Nitrogen $\cdot$ Phormidium $\cdot$ Phosphorus $\cdot$ River flow Temperature Resale or republication not permitted without written consent of the publisher

\section{INTRODUCTION}

Toxic cyanobacterial proliferations causing human and animal poisonings and fatalities have been documented in fresh and brackish waters worldwide. These events have commonly been linked to ingestion of toxins produced by planktonic Cyanobacteria (Negri et al. 1995, Kuiper-Goodman et al. 1999, Saker et al. 1999, Azevedo et al. 2002). However, animal toxicosis linked to benthic Cyanobacteria has increased recently (Mez et al. 1997, Hamill 2001, Gugger et al. 2005, Cadel-Six et al. 2007, Wood et al. 2007, 2010). The physical, chemical, and biological parameters leading to planktonic cyanobacterial blooms have been extensively studied (e.g. Oliver \& Gnaf 2000), as have variables regulating toxin production by planktonic species (see Sivonen \& Jones 1999 for review). In contrast, research on benthic Cyanobacteria has been initiated largely in response to animal poisonings and has focused on characterising the causative cyanobacterium and toxin and the symptoms in effected organisms (e.g. CadelSix et al. 2007, Wood et al. 2010). There is a limited understanding of mechanisms leading to benthic cyanobacterial proliferations and the influences of environmental variables on regulating toxin production of benthic species.

Benthic Cyanobacteria produce most of the known cyanotoxins, e.g. microcystins (Mez et al. 1997, Wood et al. 2010), saxitoxins (Carmichael et al. 1997), and cylindrospermopsins (Seifert et al. 2007). In New 
Zealand, anatoxin-a (ATX) and homoanatoxin-a (HTX) are the most commonly detected cyanotoxins produced by benthic species (Wood et al. 2007, Heath et al. 2010). These are powerful neuromuscular blocking agents acting through the nicotinic acetylcholine receptor. In affected animals they can cause convulsions, coma, rigors, cyanosis, limb twitching, hypersalivation, and/or death. Research on the regulation of ATX in planktonic species has revealed that toxin production varies among species and with different physicochemical factors, e.g. temperature, light, and phosphorus (Rapala et al. 1993, Rapala \& Sivonen 1998). Few studies have investigated ATX regulation and production in benthic mat-forming Cyanobacteria, despite the evident risk posed to human and animal health.

In November 2005, at least 5 dogs died rapidly after contact with water from the Hutt River (lower North Island, New Zealand). Dense mats of Phormidium autumnale were found in the river, and ATX and HTX were identified in the mats and dog stomach contents (Wood et al. 2007). Increased monitoring of Cyanobacteria in subsequent summers identified extensive coverage of Phormidium throughout the middle and lower reaches of the river, and further Cyanobacteria related dog deaths were reported. Phormidium mats were also

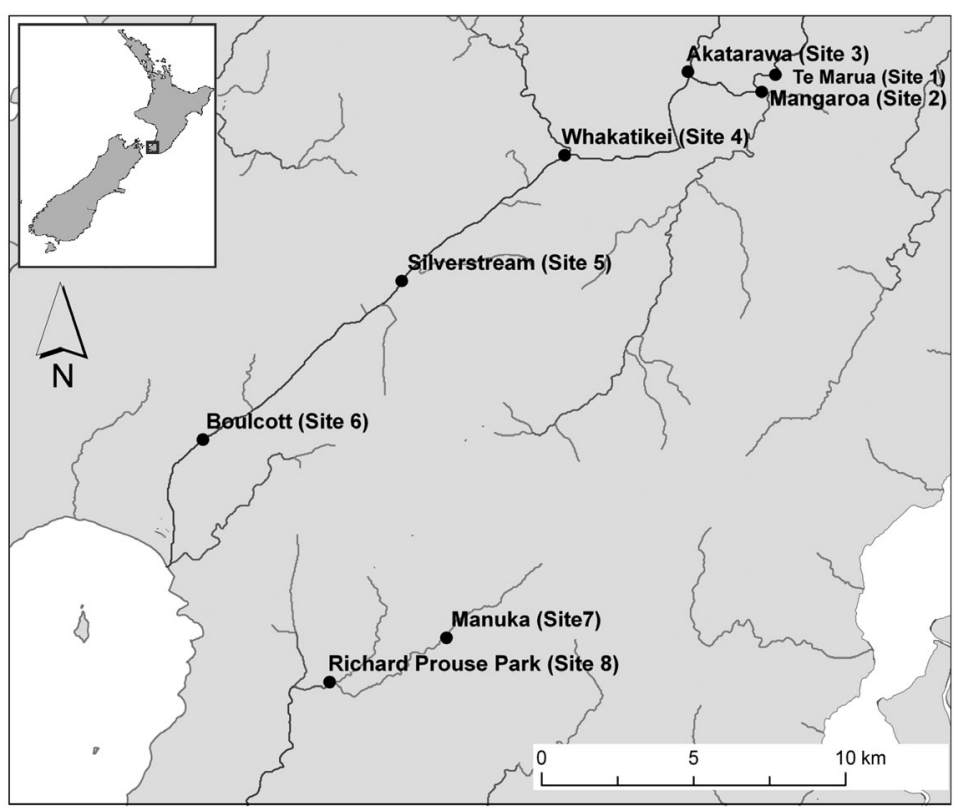

Fig. 1. Locations of sampling sites. Sites 1 to 6 are located in the Hutt River and tributaries, and Sites 7 and 8 in the Wainuiomata River, Wellington, New Zealand. Site coordinates: Site 1: E: 2689075 N: 6010880; Site 2: E: 2688625 N: 6010315; Site 3: E: 2686195 N: 6010975; Site 4: E: 2681885 N: 6008350; Site 5: 2676780 N: 6004090; Site 6: E: 2670240 N: 5998870; Site 7: E: 2678253 N: 5992345; Site 8: E: $2674410 \mathrm{~N}: 5990890$ detected in other rivers in the region (Milne \& Watts 2006, Wood et al. 2007), including the Wainuiomata River (Fig. 1)

In this study, 6 sites along the Hutt River and its tributaries, and 2 sites on the Wainuiomata River were surveyed and sampled for 1 yr. Surveying and sampling was undertaken fortnightly during periods of flushing flows or weekly when river flow was more stable. Samples were collected for species identification and ATX and HTX analysis. Monthly water samples were taken for nutrient analysis, and river flow and temperature were logged continuously at different locations along each river. Percentage cover and community composition data were used in concert with physicochemical measurements to elucidate parameters correlated with cyanobacterial mat proliferation and ATX and HTX production.

\section{MATERIALS AND METHODS}

Site descriptions. The Hutt River stretches $54 \mathrm{~km}$ south through the Hutt Valley and discharges into Wellington Harbour (Fig. 1). It runs through several populated areas and has over 1 million recreational visits each year. In its upper reaches the river is used to provide the wider Wellington metropolitan area with up to $40 \%$ of its potable water (Wood et al. 2007).

Six sites were sampled on the Hutt River and its tributaries and 2 on the Wainuiomata River (Fig. 1). These were selected based on historical knowledge of high benthic cyanobacterial abundance at these locations. The sites were ranked based on a Water Quality Index (WQI) that relies on 6 variables: visual clarity (black disc), dissolved oxygen, dissolved reactive phosphorus, ammoniacal nitrogen, nitrate nitrogen, and faecal coliforms (Perrie 2007). The sites ranged in water quality between 'poor' and 'excellent' (Table 1). Coarse greywacke, a hard sedimentary rock, was the dominant substrate found at all 8 sites. The Sites 2, 3 and 4 were located on feeder tributaries to the Hutt River just above their confluence.

Data and sample collection. At each site, cyanobacterial mat and periphyton percentage substrate coverage was measured in three $1 \mathrm{~m}^{2}$ quadrats, randomly positioned within a larger $10 \mathrm{~m}^{2}$ quadrat, in a run (a swiftly flowing region of river with a relatively smooth surface). The data from the three $1 \mathrm{~m}^{2}$ quadrats were averaged to estimate the percentage cover for each $10 \mathrm{~m}^{2}$ quadrat. Samples were collected within each $10 \mathrm{~m}^{2}$ quadrat by scraping mat material 


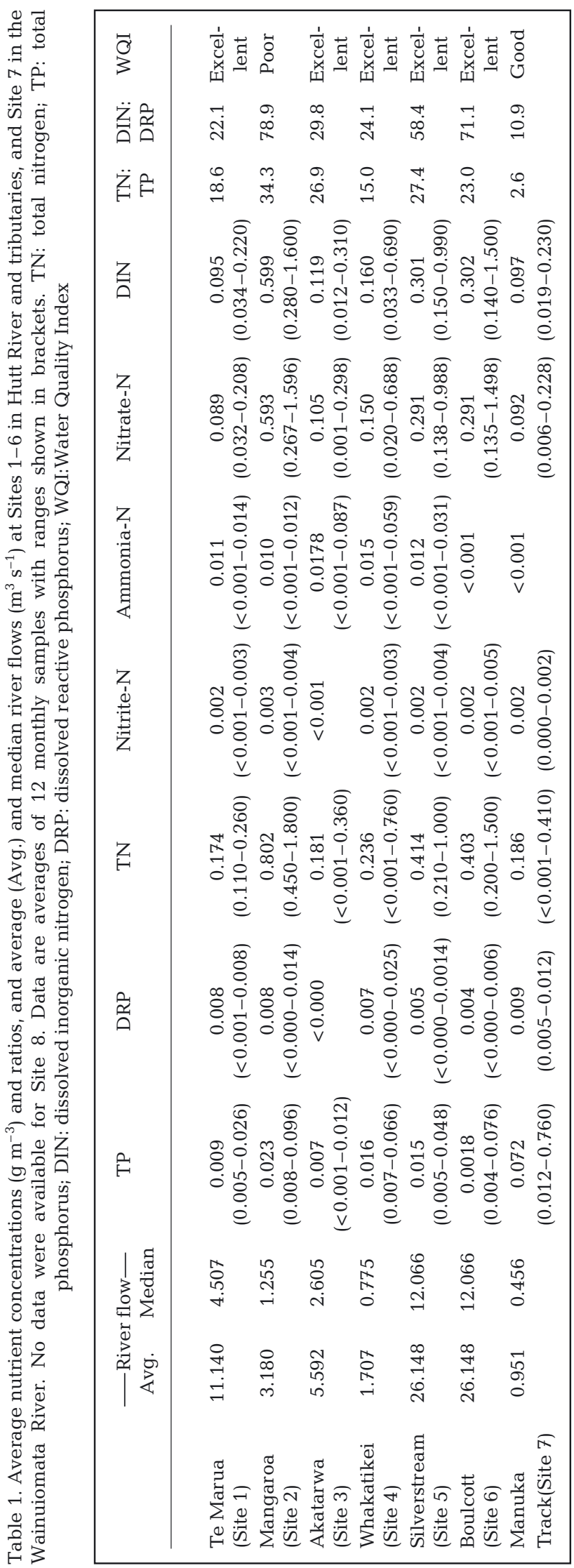

from rocks into a sterile plastic screw-cap bottle $(50 \mathrm{ml}$, Biolab, New Zealand). All samples were placed on ice for transport. On arrival at the laboratory, samples were frozen $\left(-20^{\circ} \mathrm{C}\right)$ for toxin analysis or preserved using Lugol's Iodine for morphological identification. Continuous river flow and water temperature data were measured at sampling sites using either Campbell C107 or Unidata LM34 sensors. Continuous readings for Site 4 were obtained from a logger $10 \mathrm{~km}$ upstream and readings for Sites 5 and 6 from a logger positioned midway between the 2 sites. We calculated the average river flow over the 12 mo period for each river $(\mathrm{Fa})$. This yearly average value was used to standardise the river flow data as $\mathrm{F} / \mathrm{Fa}$ (times above average), where $\mathrm{F}$ is the river flow at the time of sampling. $F / F$ a was used as a potential predictor for our statistical analysis. No water temperature was recorded for Sites 4, 7 and 8 and no river flow for Site 8. Water samples were collected monthly at Sites 1 to 7 to determine nitrate-N, nitrite-N, ammonia-N, total nitrogen, total kjedahl nitrogen, dissolved reactive phosphorus, and total phosphorus. No water samples were collected at Site 8. Samples for dissolved nutrients were filtered through $45 \mu \mathrm{m}$ Whatman $\mathrm{GF} / \mathrm{C}$ filters and frozen $\left(-20^{\circ} \mathrm{C}\right)$ until further analyses.

Species identification. Subsamples of the preserved field samples were homogenized and allowed to settle in a cavity slide $(1 \mathrm{ml})$, and species were identified under an Olympus (CKX41) inverted microscope. Identifications were made primarily by reference to Komárek \& Anagnostidis (2005), McGregor (2007), and Biggs \& Kilroy (2000).

Extraction and detection of anatoxin-a and homoanatoxin-a. Frozen mat material was lyophilized (FreeZone6, Labconco). Lyophilized material (100 mg) was resuspended in $10 \mathrm{ml}$ of double distilled water (DDW) containing $0.1 \%$ formic acid and sonicated (Cole Parmer 8890, Biolab) for 15 min. Samples were centrifuged $(4000 \times g, 10 \mathrm{~min})$. The pellet was reextracted a second time using $5 \mathrm{ml}$ DDW and supernatants combined.

All samples were analysed for ATX, HTX, and their degradation products: dihydroanatoxin (dhATX), dihydrohomoanatoxin (dhHTX), epoxyanatoxin-a (epATX), and epoxyhomoanatoxin-a (epHTX), using liquid chromatography-mass spectrometry (LC-MS). Anatoxins were separated by Acquity uPLC (Waters Corp.) using a $50 \times 1.0 \mathrm{~mm}$ Acquity BEH-C18 $(1.7 \mu \mathrm{m})$ column (Waters Corp.). The mobile phase A ( $0.1 \%$ formic acid in water) and mobile phase B ( $0.1 \%$ formic acid in acetonitrile) were used at a flow of $0.3 \mathrm{ml} \mathrm{min}^{-1}$, isocratic for $1 \mathrm{~min}$ at $100 \% \mathrm{~A}$, followed by a gradient to $50 \% \mathrm{~B}$ over 2 min. Injection volume was $5 \mu$ l. The Quattro Premier XE mass spectrometer (Waters-Micromass) was operated in ESI+ mode with capillary voltage $0.5 \mathrm{kV}$, desolvation gas $900 \mathrm{l} \mathrm{h}^{-1}, 400^{\circ} \mathrm{C}$, cone gas $200 \mathrm{l} \mathrm{h}^{-1}$ and 
cone voltage $25 \mathrm{~V}$. Quantitative analysis was by multiple reaction monitoring (MRM) using MS-MS channels set up for ATX (166.15 > 149.1; retention time (rt) 1.0 $\min ), \operatorname{HTX}(180.2>163.15$; rt ca. $1.9 \mathrm{~min})$, dhATX (168.1 > 56; rt $0.9 \mathrm{~min})$, and dhHTX (182.1 > 57; rt ca. $1.9 \mathrm{~min})$. The instrument was calibrated with dilutions in $0.1 \%$ formic acid of authentic standards of ATX (A.G. Scientific).

Nutrient analyses. Filtered nutrients were analysed on a Lachat QuickChem FLOW Injection Analyser (FIA + 8000 Series, Zellweger Analytics) and a Konelab Aquakem 600 Discrete Analyser (Thermo Scientific). Nitrite- $\mathrm{N}$ was analysed using automated AZO dye colorimetry, and total oxidised nitrogen (nitrate- $\mathrm{N}+$ nitrite-N) were analysed using automated cadmium reduction following the methods of the American Public Health Association (Eaton et al. 2005). Total kjedahl nitrogen was digested in sulphuric acid and analysed using phenol/hypochlorite colorimetry (Eaton et al. 2005). Nitrate was calculated by subtracting nitrite-N from total oxidised nitrogen (nitrate- $\mathrm{N}+$ nitrite- $\mathrm{N}$ ), and total nitrogen was calculated by the addition of total kjedahl nitrogen, nitrite-N, and nitrate-N. Total phosphorus was digested with acid persulphate before using ascorbic acid colorimetry (Eaton et al. 2005). Dissolved reactive phosphorus was analysed using molybdenum blue colorimetry (Eaton et al. 2005).

Statistics. Stepwise logistic regression was used to establish the best predictors of Phormidium mat coverage and ATX and/or HTX presence across all 8 sites. No physicochemical data were collected for Site 8, and therefore this site was excluded from the analysis. Predictors were considered significant at the 95\% (p < $0.05)$ confidence interval. River flow and water temperature were found to be significant predictors. In all cases, binary predicative's were improved by altering the default of 0.5 probability to a cut value that maximised the prevalence of the presences in the data. This decreased the probabilities of false negatives (i.e. Cyanobacteria predicted to be absent when in fact it was present).

For water temperature and river flow $\left(\mathrm{m}^{3} \mathrm{~s}^{-1}\right)$, a 5-day average prior to sampling was correlated with each sampling point. Standardisation of river flow was achieved by dividing the 5-day average river flow by yearly average river flow. All data were analysed using SPSS Statistical Software, version 16.0.

\section{RESULTS}

\section{Nutrients}

Total nitrogen (TN) and total phosphorus (TP) were generally found at low levels throughout the course of this investigation (Table 1). The lowest nutrient loadings were observed at the head waters of both the Hutt (Site 1, TN $0.174 \mathrm{~g} \mathrm{~m}^{-3}$, TP $0.009 \mathrm{~g} \mathrm{~m}^{-3}$ ) and Wanuiomata (Site 7, TN $0.074 \mathrm{~g} \mathrm{~m}^{-3}$, TP, $0.072 \mathrm{~g} \mathrm{~m}^{-3}$ ) rivers, whilst the highest concentration were found in the lower reaches of the Hutt River (Site 6, TN $0.403 \mathrm{~g}$ $\mathrm{m}^{-3}$, TP $0.018 \mathrm{~g} \mathrm{~m}^{-3}$ ) and at Site 2, which had increased nitrogen and phosphorus levels (TN $0.802 \mathrm{~g} \mathrm{~m}^{-3}$, TP $0.023 \mathrm{~g} \mathrm{~m}^{-3}$ ). Site 7 had a low TN:TP ratio (2.6); the remaining sites all had ratios above 15 , with Sites 2, 5 and 6 above 25 with ratios of 34.3, 26.9, and 27.4, respectively. The TN:TP ratios increased with distance down the river. A $t$-test found there was no significant difference between $\mathrm{N}: \mathrm{P}$ ratios with and without the presence of Phormidium mats ( $p=0.3350$, df $=89$ ).

\section{Temporal and spatial variability in Phormidium mat abundance}

Cyanobacterial mats were recorded at all 8 study sites. The dominant genus in these mats was Phormidium. Although genetic analysis was not conducted as part of this study, polyphasic analyses of samples collected simultaneously identified Phormidium autumnale as the dominant cyanobacterium in the mats (Heath et al. 2010). Species from the Pseudanabaenaceae family such as Leptolyngbya spp. and Pseudanabaena spp. were observed in low concentrations within the mats (Heath et al. 2010). Phormidium mats were generally most abundant in summer and less frequently observed in winter (between May and October 2008). This higher coverage coincided with periods of stable river flow and warmer water temperatures (Fig. 2).

Percentage Phormidium mat cover was often over $50 \%$ at 4 of the 6 Hutt River sites (Sites 2, 3, 5 and 6) during summer, with the highest coverage (70\%) observed at Sites 2 (6 January 2008) and 5 (27 February 2008) (Fig. 2). At Site 1, Phormidium mats were observed from the initial sampling (6 December 2007) until the 6 January 2008 (Fig. 2a). Mats were not present again until late February 2008, when the maximum percentage cover was less than $10 \%$. Site 2 had extensive Phormidium mat coverage at the time of initial sampling (peaking at $70 \%, 6$ January 2008), this steadily decreased until there were no Phormidium mats observed (26 March 2008; Fig. 2b). Phormidium mat coverage (up to $25 \%$ ) was recorded in May and June 2008 and then no mats were observed until November 2008. No Phormidium mats were observed at Site 3 in January and only minimal coverage $(<15 \%)$ in February (Fig. 2c). In March 2008, Phormidium mat coverage peaked at $60 \%$, and then occurred sporadically in April and May 2008 before consistent mats 


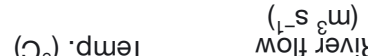

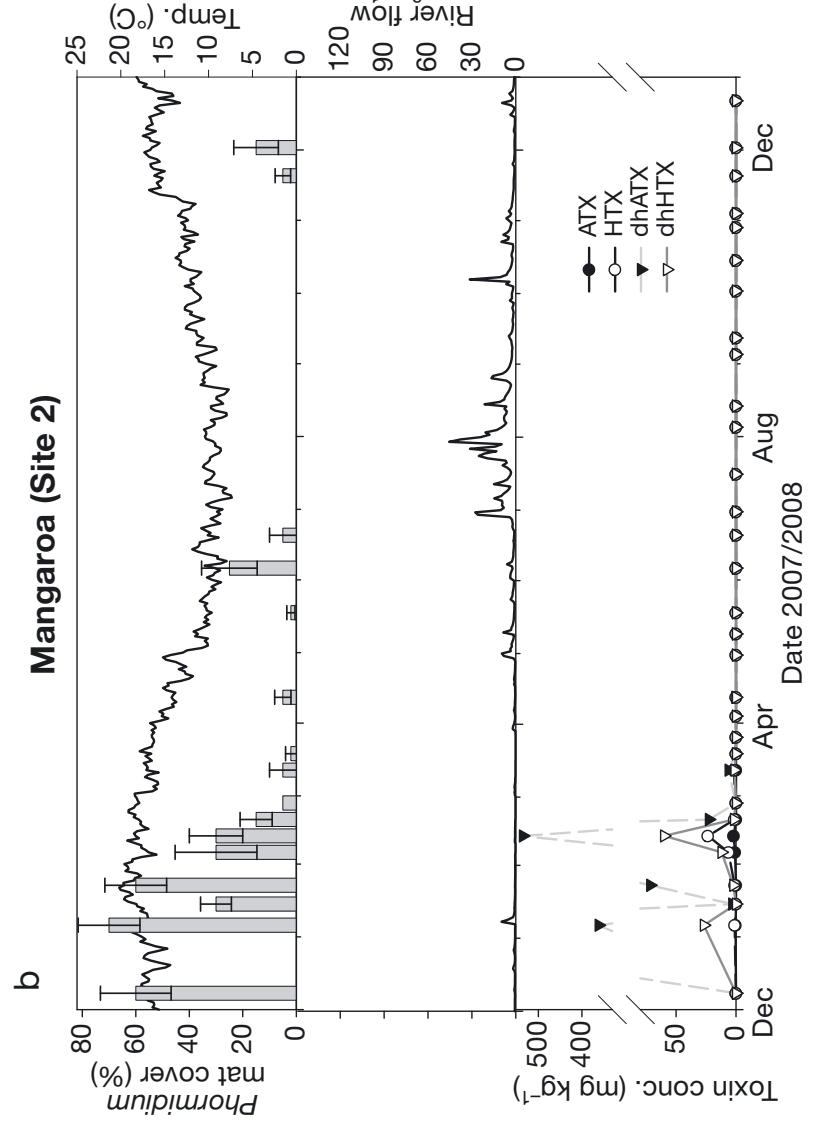

$\left({ }_{\llcorner-} s_{\varepsilon} m\right)$

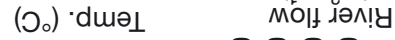

ผ ำ 눈

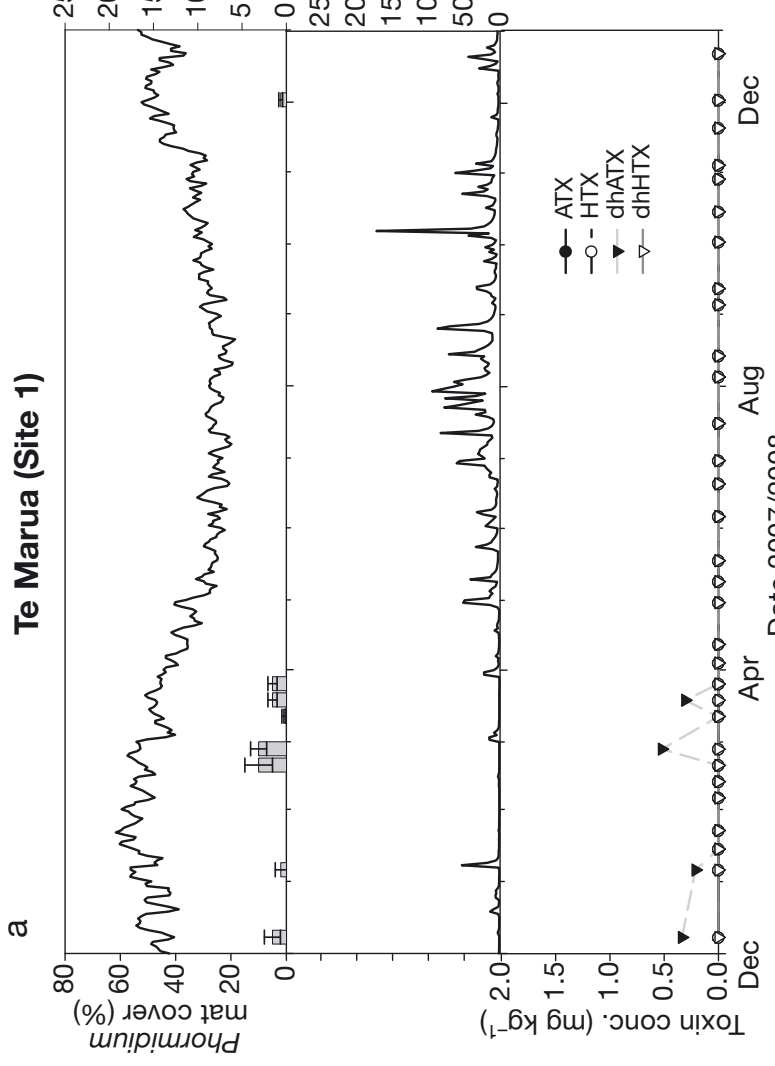

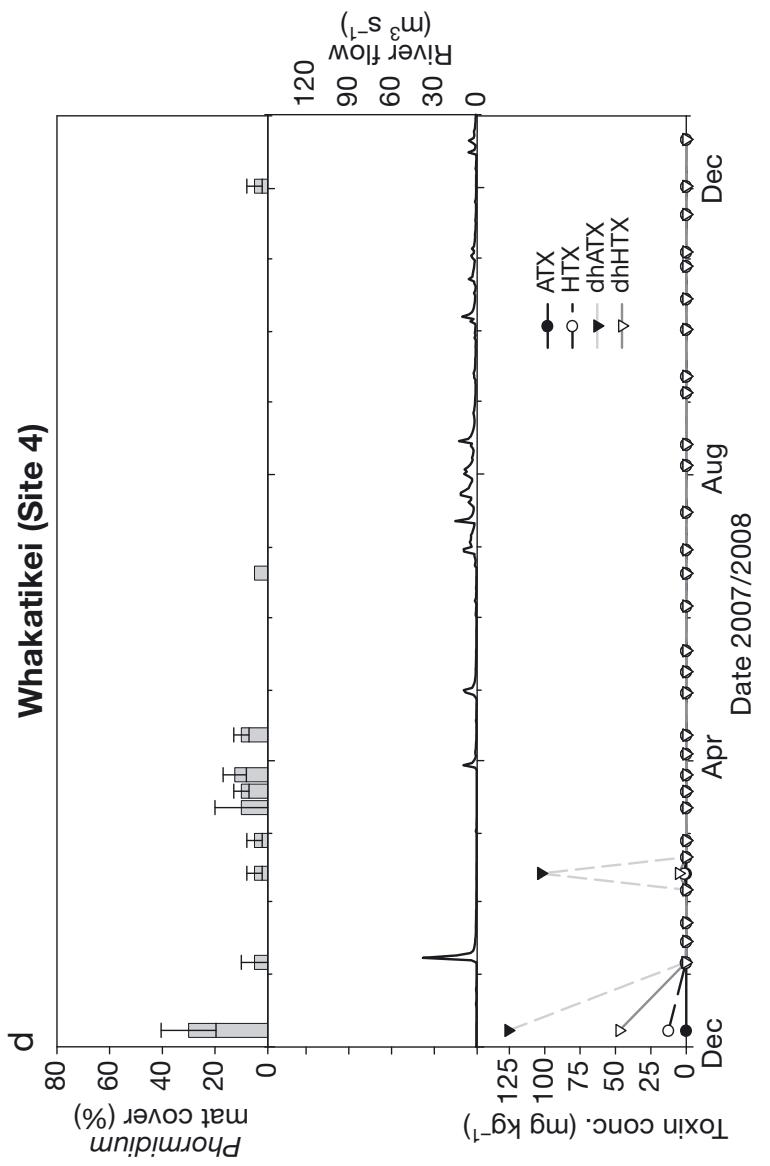

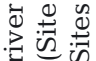

룰

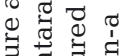

语

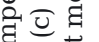

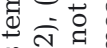

प 0 व

बi

ป

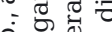

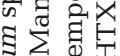

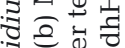

I $=\bar{\pi}$

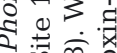

4 近 $\infty$

ปี

范茫

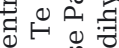

ชิ

ठ둥

율 웜

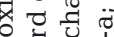

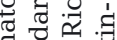

증 ฮี త્વ

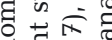

过点

त过

$\exists$ 兒光

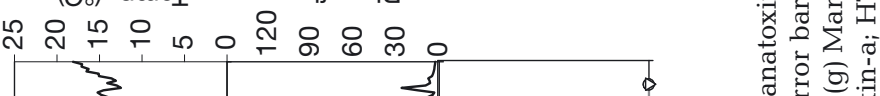

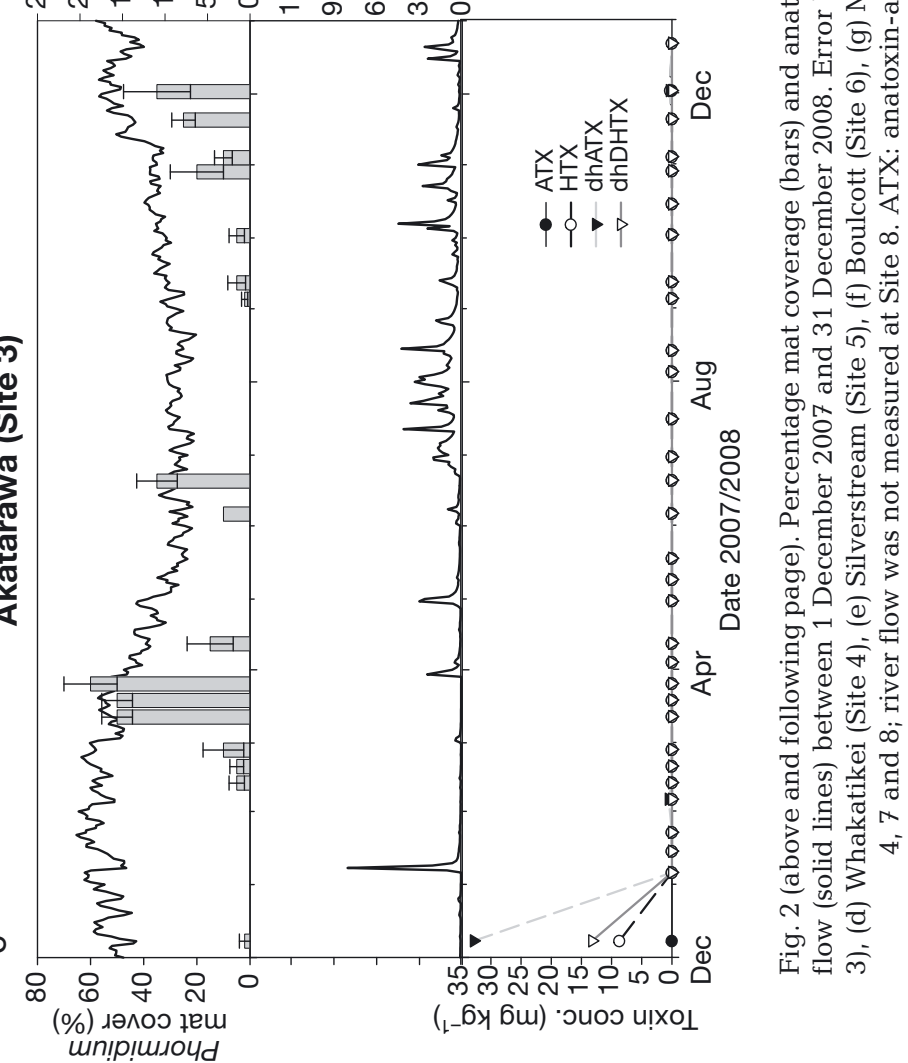




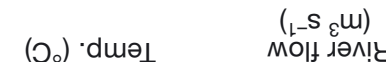

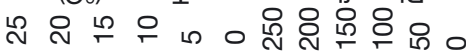
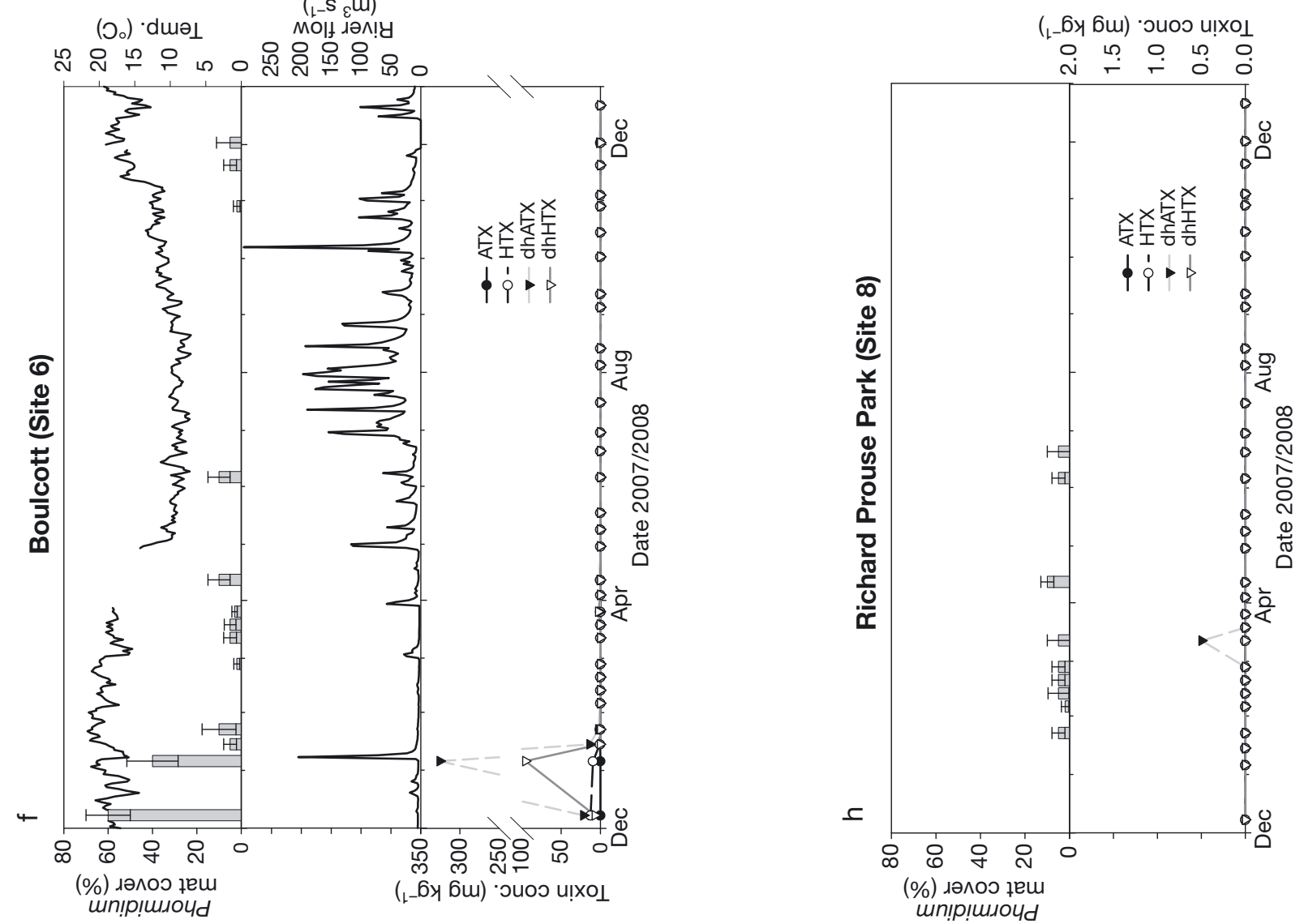

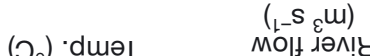

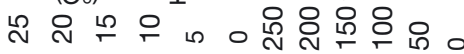
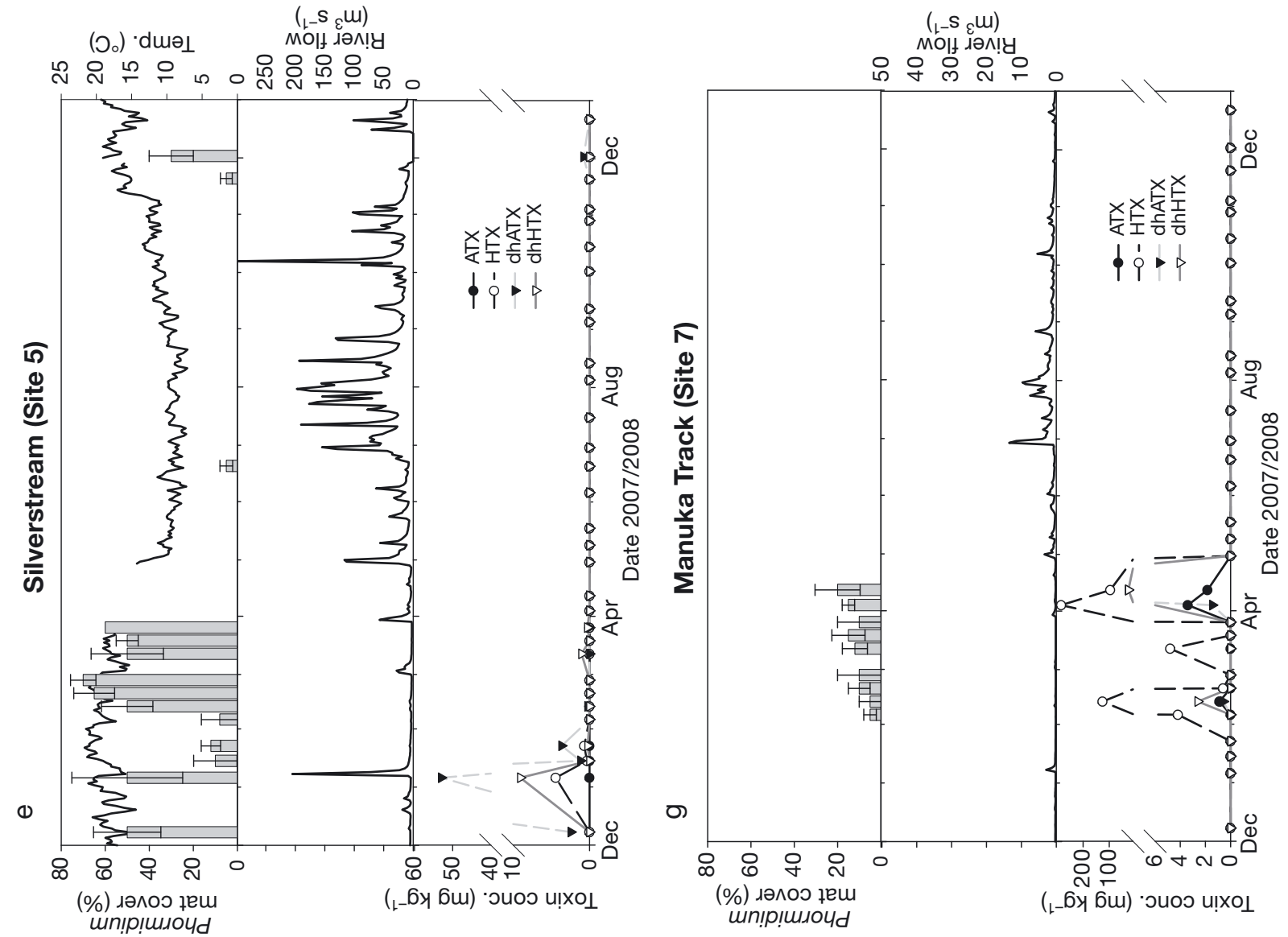
were observed between September and December 2008 (Fig. 2c). Site 4 experienced peak Phormidium coverage in December 2007 (30\%) and patchy or low $(<10 \%)$ percentage cover between January and March 2008 (Fig. 2d). Low (<15\%) Phormidium mat cover was observed once in April and once in June 2008 with no further mats recorded until December 2008. Consistent Phormidium mat coverage $(<40 \%)$ was observed at Site 5 from December 2007 to the end of March 2008. After that, Phormidium mats (5\%) were observed once in June 2008 and were not recorded again until November 2008 (Fig. 2e). Phormidium mat abundance at Site 6 peaked at $60 \%$ in December 2007 and early January 2008. Throughout the rest of the sampling period, abundance was patchy and low $(<10 \%$; Fig. 2f).

There was no Phormidium sp. mat coverage at Site 7 (Wainuiomata River) until February 2008. Consistent coverage was then observed until the end of March 2008, where it peaked at $15 \%$ (Fig. 2g). Phormidium coverage at Site 8 was low and patchy, with consistent coverage only observed from late January 2008 to early March 2008. No Phormidium mat coverage was observed after June 2008 (Fig. 2h).

\section{Predicting the presence of Phormidium mats}

Using stepwise logistic regression, river flow and water temperature were identified as the only significant physicochemical parameters $(\mathrm{p}<0.05)$ correlated with the presence of Phormidium mats. Consequently these were the only variables included in the logistic model (Fig. 3). At a cut value of 0.5 , the model successfully predicted $80.9 \%$ of the observed results, correctly predicting $82.6 \%$ of the times where Phormidium mats were absent and $78.8 \%$ of the time they were present. Using this model the probability of Phormidium mats (P) occurring for any given river flow and water temperature can be calculated (Fig. 3b). The model demonstrates that with a yearly average river flow (1 in the model: refer to Table 1 for yearly average river flows) and water temperatures of $15^{\circ} \mathrm{C}$, the probability of Phormidium mats occurring is $31 \%$. With a river flow value of 0.5 and water temperatures of $20^{\circ} \mathrm{C}$, the probability is $71 \%$ (Fig. $3 b$ ).

\section{Spatial and temporal variation in anatoxin-a and homoanatoxin-a}

ATX and/or HTX were detected at all Hutt River sites, and concentrations were highly variable, both within and between sites (Fig. 2a-f). The highest concentrations of ATX $\left(1.7 \mathrm{mg} \mathrm{kg}^{-1}\right)$, HTX $\left(23.5 \mathrm{mg} \mathrm{kg}^{-1}\right)$, and
dhATX ( $535 \mathrm{mg} \mathrm{kg}^{-1}$ ) were all observed at Site 2 (13 February 2008), and the highest concentration of dhHTX (95.4 $\mathrm{mg} \mathrm{kg}^{-1}$ ) was detected at Site 6 (6 January 2008). Some temporal similarities were observed, with maximal ATX and/or HTX concentrations occurring at Sites 3 and 4 on 6 December 2007, at Sites 2, 5 and 6 on 6 January 2008 and Sites 1, 2 and 4 on 12 February 2008 (Fig. 2a-f). ATX was only detected at Sites 2 and 6, while HTX was observed at all sites, with the exception of Site 1. The
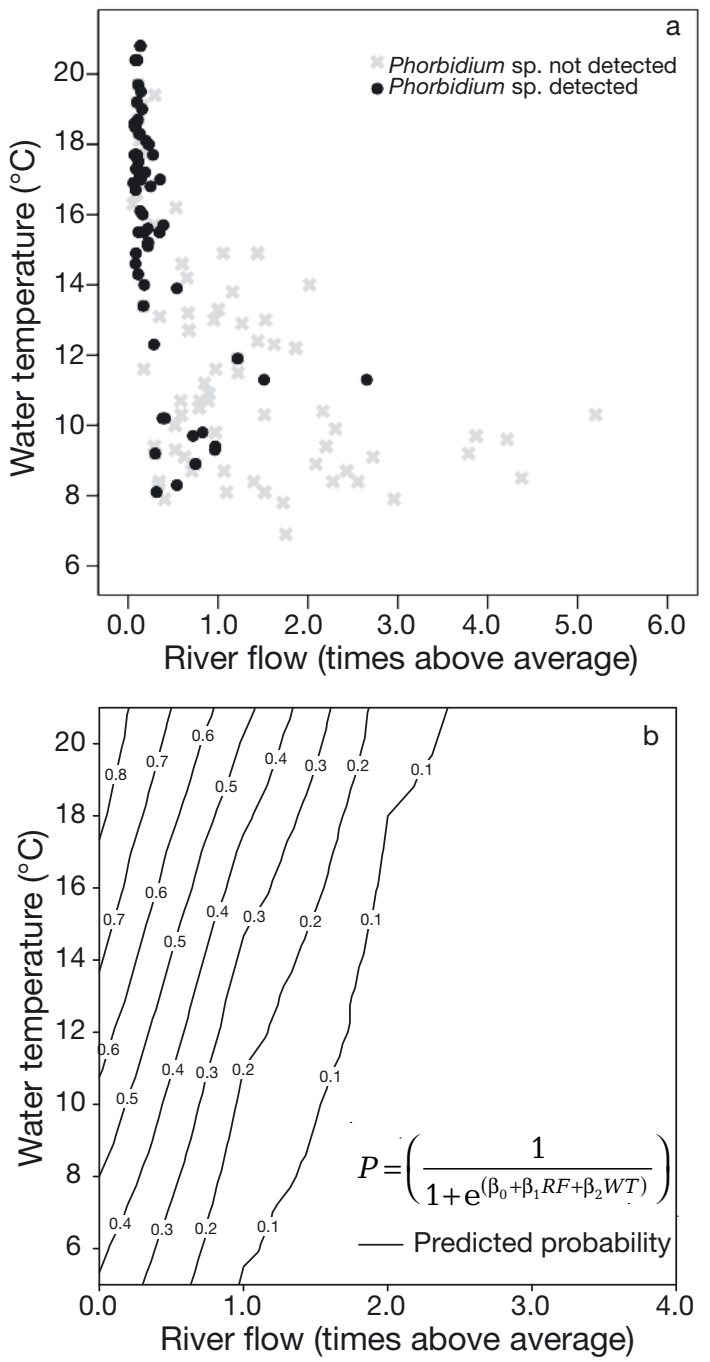

Fig. 3. Phormidium sp. (a) Scatter plot of water temperature versus river flow where cyanobacterial mats were present and absent. (b) Contour plot showing predicted probability of mats being present in the Hutt River (New Zealand) given different magnitudes of river flow and water temperature. The model was derived from observed field data. The predicted probability $(P)$ of the occurrence of Phormidium mats can be derived using the logistic equation where river flow $(R F)$ and water temperature $(W T)$ are known. Constants: $\beta_{0}=$ $-1.208, \beta_{1}=-1.821, \beta_{2}=0.150$. Note, river flow has been standardised for different rivers as a ratio $\mathrm{F} / \mathrm{Fa}$ and is thus expressed as times above the yearly average flow (see 'Materials and methods') 
most common compound, dhATX, was found at all sites, while dhHTX was observed at all sites except Site 1. At all Hutt River sites degradation products (dhATX and dhHTX) were always found in much higher concentration than their parent compounds, and dhATX was con-
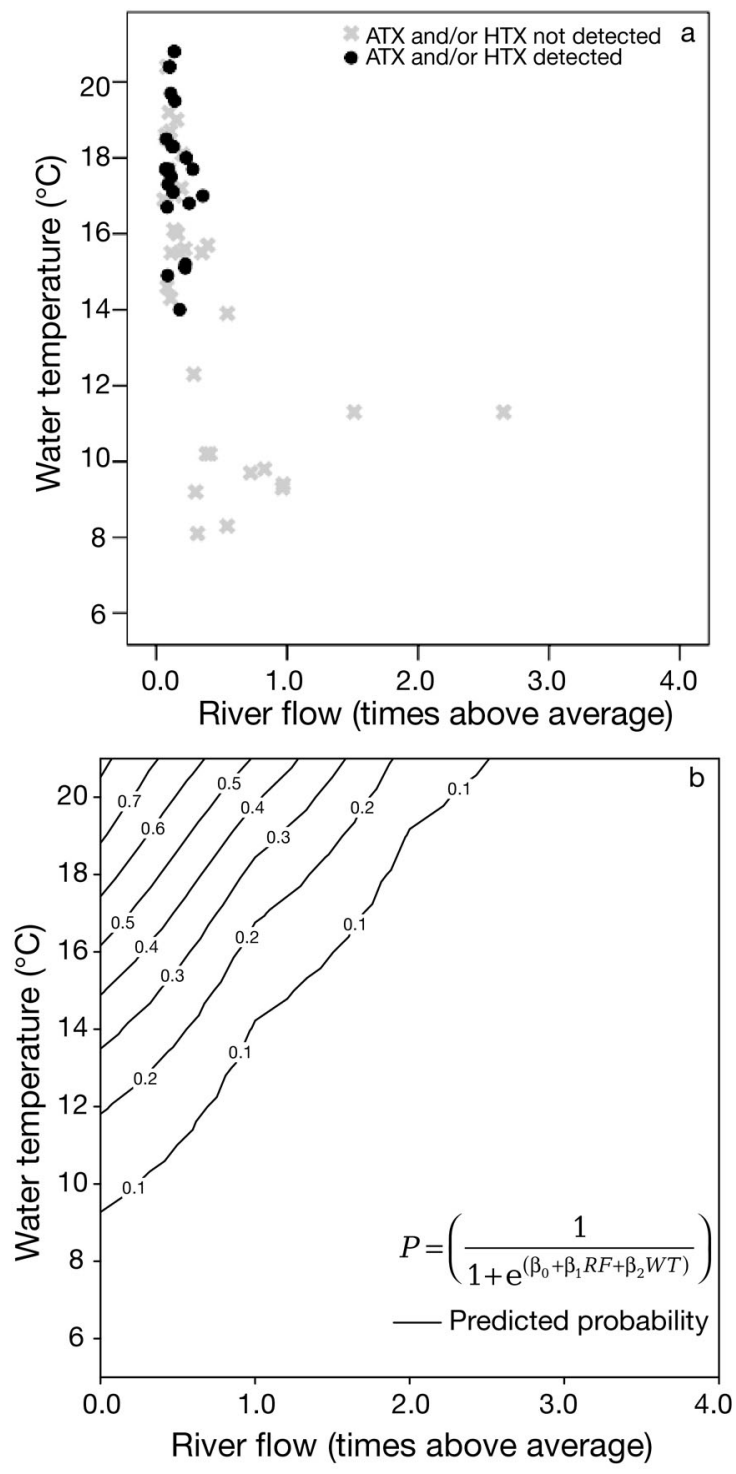

Fig. 4. (a) Scatter plot of water temperature versus river flow showing the presence and absence of anatoxin-a (ATX) and homoanatoxin-a (HTX) where Phormidium mats were detected. (b) Contour plot showing the predicted probability of ATX and/or HTX being present in the Hutt River and Wainuiomata river (New Zealand) given different magnitudes of river flow and water temperature, when Phormidium mats are present. The model was derived from observed field data. The predicted probability $(P)$ of the occurrence of ATX and/or HTX can be derived using the logistic equation where river flow (RF) and water temperature (WT) are known. Constants: $\beta_{0}=-5.172, \beta_{1}=-1.585, \beta_{2}=0.320$. Note, river flow has been standardised for different rivers as a ratio $\mathrm{F} / \mathrm{Fa}$ and is thus expressed as times above the yearly average flow (see 'Materials and methods') sistently found in higher concentrations than dhHTX. ATX and/or HTX were only detected in the summer and spring, i.e. December 2007 to April 2008 (Fig. 2a-f).

At the Wainuiomata River, no anatoxins were detected at Site 8 except on 14 March when dhATX $\left(0.5 \mathrm{mg} \mathrm{kg}^{-1}\right)$ was detected (Fig. 2h). In contrast ATX, HTX, and their degradation products were detected at Site 7 (Fig. 2g). The highest concentrations of ATX (3.4 mg kg-1) and HTX (283 $\mathrm{mg} \mathrm{kg}^{-1}$ ) at this site were both recorded on 4 April 2008 (Fig. 2g). This was the only site where the parent toxins (ATX and HTX) were found in higher concentrations than their degradation products.

Rapid temporal changes in anatoxin concentrations were observed, despite there being little change in Phormidium sp. percentage cover. For example, at Site 2 the combined ATX, HTX, dhATX, and dhHTX concentration increased from $201 \mathrm{mg} \mathrm{kg}^{-1}$ on 6 February 2008 to $620 \mathrm{mg} \mathrm{kg}^{-1}$ on 13 February 2008, without any change in Phormidium mat coverage (Fig. 2b). At Site 7, on 13 February 2008, the combined ATX, HTX, dhATX, and dhHTX concentration was $129.8 \mathrm{mg} \mathrm{kg}^{-1}$, but 1 wk later on 20 February, HTX was the only compound detected (0.6 mg kg ${ }^{-1}$; Fig. $2 \mathrm{~g}$ ).

\section{Factors contributing to anatoxin-a and homoanatoxin-a presence/absence}

Logistic regression was used to determine the best predictors of ATX and/or HTX presence/absence when Phormidium mats were present. Water temperature and river flow were the only significant $(p<0.05)$ physicochemical predictors of toxin presence. The logistic model successfully predicted $72.1 \%$ of the observed results, correctly predicting $64.7 \%$ of the times when ATX and/or HTX were absent and 81.5\% of the time when they were present. ATX and/or HTX were observed to occur in water temperatures $>13.4^{\circ} \mathrm{C}$. Furthermore, ATX and/or HTX were only detected when river flows were low (below half the yearly average) and stable. The logistic model shows that when river flow is average ( 1 in the model) and water temperature is $15^{\circ} \mathrm{C}$, the probability of ATX and/or HTX being detected when mats are present is $28 \%$. At a river flow value of 0.5 and a water temperature of $20^{\circ} \mathrm{C}$ the probability increases to $72 \%$ (Fig. 4).

\section{DISCUSSION}

\section{Phormidium mat presence and physicochemical parameters}

The data from the Hutt and Wainuiomata rivers demonstrate that Phormidium mat coverage can be 
highly variable spatially and temporally within rivers. Despite this variation, a seasonal factor contributing to Phormidium mat coverage was apparent. Peaks in Phormidium mat coverage for all sites were observed in summer (December to March). Similar trends in total periphyton (including cyanobacterial mats) have been documented previously in New Zealand and have been attributed to a lower frequency of flushing river flows during summer (Biggs \& Price 1987, Biggs \& Close 1989, Biggs 1990, Clausen \& Biggs 1997).

In this study, river flow and water temperature were found to be significant physicochemical parameters predicting Phormidium mat coverage. High river flows have the ability to pick up rocks and pebbles, and thereby remove attached mat material from substrates (Biggs \& Close 1989). Water turbulence has been previously described as a major controlling factor for benthic Cyanobacteria in river systems (Biggs 1990, Milne \& Watts 2006, Wood et al. 2007), lake systems (Johnson \& Castenholz 2000, Dasey et al. 2005), and marine environments (Thacker \& Paul 2001). The ability of river flow to flush Phormidium mats has led local government agencies in the Wellington region to adopt this measure as one of the factors used to predict Phormidium mat percentage coverage (Milne \& Watts 2006). Two weeks without a river flow of 3 times the long term median is used as an early warning indicator of the strong likelihood of benthic Phormidium mat proliferation.

Water temperature was shown to have a strong positive relationship with Phormidium mat coverage. This was consistent with Biggs (1990) who has previously elucidated temperature as a significant parameter in Lyngbya (a cyanobacterium that can also grow on the benthos) proliferations in New Zealand rivers. Furthermore, this is consistent with previous planktonic Cyanobacteria research, where optimal temperatures maximise growth (Robarts \& Zohary 1987, Song et al. 1998). The model developed in this study successfully predicted $80.9 \%$ of our field observations. The probability of Phormidium sp. being present dramatically increased when river flow was half the yearly average and water temperature above $14^{\circ} \mathrm{C}$. These results support Greater Wellington Regional Council's use of river flow as a predictor of the presence of mat-forming benthic Phormidium sp., and suggest that water temperature should be incorporated into the model for greater predicative power.

No other physicochemical parameters were significant predictors of Phormidium mat presence. Research on planktonic and benthic Cyanobacteria in marine, lake, and culture environments has shown nutrients such as phosphorus and nitrogen to be key parameters responsible for growth (Paerl 1996, Downing \& Watson 2001, Vilalta et al. 2003). In New Zealand, benthic
Cyanobacteria have previously been identified proliferating in sites with low nutrients (Biggs \& Price 1987, Biggs 1990). Some Cyanobacteria from the LPP (Lyngbya, Phormidium, Plectonema) group possess the ability to fix nitrogen, therefore enhancing their ability to persist in nitrogen poor environments (Bergman et al. 2006, Pankratova et al. 1998). Low levels of DIN observed throughout this investigation may favour algal species with the ability to fix atmospheric nitrogen. At Site 2, expansive proliferations of chain diatom Melosira varians were observed; coincidently, this was the only site with elevated DIN levels. Those sites with the highest cyanobacterial coverage $(2,3,5$ and 6$)$ were found to have high TN:TP ratios (above 20:1) providing evidence that nitrogen, rather than phosphorus, may be the nutrient limiting Phormidium mat growth (Borchardt 1996). It has been suggested that essential nutrients can be sourced from the geology of the surrounding catchment (Leland \& Porter 2000), and therefore it is plausible that nutrients can be dissolved from the substratum and utilised. Biggs (1990) found that Lyngbya proliferations were highly associated with hard sedimentary rocks, which provide a potential source of phosphorus.

\section{Spatial and temporal variation in anatoxin-a and homoanatoxin-a production}

The presence/absence and concentrations of ATX and/or HTX varied between sites and over time. In New Zealand, some water managers use set thresholds of Phormidium sp. percentage coverage to issue health warnings (Wood et al. 2009). In this study, we found no correlation between the coverage of Phormidium mats and ATX and/or HTX concentrations. Previous investigation have shown that cyanobacterial mats consist of mixed toxic and non-toxic strains of Phormidium autumnale (Cadel-Six et al. 2007, Heath et al. 2010). It is possible that the variations in ATX and/or HTX concentrations observed in this study were due to changes in the relative abundances of toxic and non-toxic Phormidium strains in a mat, rather than changes in the amount of ATX and/or HTX produced. Previous studies have indicated that ATX quota's only vary 1 to 7 fold as environmental factors (i.e., temperature) are manipulated (Sivonen \& Jones 1999). Up and downregulations in ATX production are therefore unlikely to explain the variability observed among sampling sites in this study.

River flow and water temperature were the only significant parameter in the logistic model used to predict ATX and/or HTX presence. The model successfully predicted $72.1 \%$ of our field observations, successfully predicting $81.5 \%$ of the times ATX and/or HTX was 
present. Toxins were only detected in mats when temperatures were above $13.4^{\circ} \mathrm{C}$ and river flows were below half the yearly average. Research on some planktonic cyanobacteria has shown changes in ATX production with temperature; however, even at low temperatures, toxic genotypes still produce toxins (Rapala et al 1993, Rapala \& Sivonen 1998). Toxin production at all temperatures, coupled with the presence of non-toxin producing mats at low river flows and warm water temperatures, suggests that these variables do not have a significant effect on the regulation of ATX and/or HTX, rather that these conditions encourage the growth of ATX and/or HTX producing strains. There is currently no method to assess the proportion of ATX and/or HTX producing strains within mats. The recent discovery of a putative genes involved in ATX and/or HTX production (Cadel-Six et al. 2009, Méjean et al. 2010) provides the opportunity to use quantitative molecular techniques to monitor levels and expressions of this gene and will enable the quantification of toxic strains within a sample. This ultimately will assist in the development of predictive models aimed at providing early warning of cyanobacterial mat proliferation and toxin production.

Dihydro- degradation product concentrations were considerably higher than their parent compounds. Anatoxin is unstable especially in sunlight and at high $\mathrm{pH}$, whereas the dihydro- degradation products are more stable (Smith \& Lewis 1987). On some sampling occasions, degradation products were the only compounds detected. The detection of these compounds may provide information of previous or nearby toxic mats and these compounds should be monitored in routine cyanotoxin analysis. At Site 7 , the concentrations of degradation products were considerably lower than that of their parent compounds. This site had extensive shading provided by overhanging vegetation. In the reduced light environment there may have been less degradation of ATX and/or HTX.

\section{CONCLUSIONS}

The results of this study revealed that percentage coverage and presence of Phormidium mats are spatially and temporally variable in the Hutt and Wainuiomata rivers. ATX and HTX concentrations were also found to vary among sampling times and sites. In contrast to previous reports, ATX and/or HTX concentrations did not correlate with Phormidium mat coverage. River flow was shown to control Phormidium mat coverage, and water temperature was identified as important for Phormidium mat growth and ATX and/or HTX production. Higher temperatures are likely to result in faster growth rates and these conditions may be more favourable for ATX and/or HTX producing strains. The ability of Phormidium to obtain essential nutrients for growth from sedimentary rock substrate and via nitrogen fixation may give it a competitive advantage in the mostly oligotrophic conditions in these rivers.

Acknowledgements: This research was funded by the Greater Wellington Regional Council science research fund, the Victoria University of Wellington strategic research fund, an Andy Ritchie Memorial Trust scholarship to $\mathrm{MWH}$, and a FRST post-doctoral fellowship (CAWX0501) to SAW. The authors thank M. Boundy and R. Van Ginkel (Cawthron Institute) for technical assistance with ATX and/or HTX analysis and J. Milne, S. Warr, L. Keenan, A. Perrie, and T. Taylor (Greater Wellington Regional Council) for assistance and support throughout this research.

\section{LITERATURE CITED}

Azevedo SMFO, Carmichael WW, Jochimsen EM, Rinehart KL, Lau S, Shaw GR, Eaglesham GK (2002) Human intoxication by microcystins during renal dialysis treatment in Caruaru, Brazil. Toxicology 181-182:441-446

> Bergman B, Gallon JR, Rai AN, Stal LJ (2006) $\mathrm{N}_{2}$ fixation by non-heterocytous cyanobacterial. FEMS Microbiol Rev 19: 139-185

> Biggs BJF (1990) Periphyton communities and their environments in New Zealand rivers. NZ J Mar Freshw Res 24: 367-386

Biggs BJF, Close ME (1989) Periphyton biomass dynamics in gravel bed rivers: the relative effects of flows and nutrients. Freshw Biol 22:209-231

Biggs BJF, Kilroy C (2000) Stream periphyton monitoring manual. National Institute of Water \& Atmospheric research, New Zealand Ministry for the Environment, Christchurch

Biggs BJF, Price GM (1987) A survey of filamentous algal proliferations in New Zealand rivers. NZ J Mar Freshw Res 21:175-191

Borchardt MA (1996) Nutrients. In: Stevenson RJ, Bothwell ML, Lowe RL (eds) Algal ecology. Academic Press, New York, p 183-227

> Cadel-Six S, Peyraud-Thomas C, Brient L, de Marsac NT, Rippka R, Mejean A (2007) Different genotypes of anatoxin-producing cyanobacteria coexist in the Tarn River, France. Appl Environ Microbiol 73:7605-7614

> Cadel-Six S, Iteman I, Peyraud-Thomas C, Mann S, Ploux O, Mejean A (2009) Identification of a polyketide synthase coding sequence specific for anatoxin-a producing Oscillatoria cyanobacteria. Appl Environ Microbiol 75: 4909-4912

> Carmichael WW, Evans WR, Yin QQ, Bell P, Moczydlowski E (1997) Evidence for paralytic shellfish poisons in the freshwater cyanobacterium Lyngbya wollei (Farlow ex Gomont) comb. Appl Environ Microbiol 63:3104-3110

> Clausen B, Biggs BJF (1997) Relationships between benthic biota and hydrological indices in New Zealand streams. Freshw Biol 38:327-342

> Dasey M, Ryan N, Wilson J, McGregor G and others (2005) Investigations into the taxonomy, toxicity and ecology of benthic cyanobacterial accumulations in Myall Lake, Australia. Mar Freshw Res 56:45-55 
Downing JA, Watson SB (2001) Predicting cyanobacteria dominance in lakes. Can J Fish Aquat Sci 58:1905-1908

Eaton AD, Clesceri LS, Rice EW, Greenberg AE (2005) Standard methods for the examination of water and waste water, 21st edn. American Public Health Association, American Water Works Association \& Water Environment Federation, Washington, DC

Gugger M, Lenoir S, Berger C, Ledreux A and others (2005) First report in a river in France of the benthic cyanobacterium Phormidium favosum producing anatoxin-a associated with dog neurotoxicosis. Toxicon 45:919-928

Hamill KD (2001) Toxicity in benthic freshwater cyanobacteria (blue-green algae): first observations in New Zealand. NZ J Mar Freshw Res 35:1057-1059

Heath MW, Wood SA, Ryan KG (2010) Polyphasic assessment of fresh-water benthic mat forming cyanobacteria in New Zealand. FEMS Microbiol Ecol 73:95-109

Johnson AC, Castenholz RW (2000) Preliminary observations of the benthic cyanobacteria of the Waldo lake and their potential contribution to lake productivity. Lake Reservoir Manag 16:85-90

Komárek J, Anagnostidis K (2005) Cyanoprokaryota 2. Teil/2nd part: Oscillatoriales. In: Budel B, Krienitz L, Gärtner G, Schagerl M (eds) Süsswasserflora von Mitteleuropa 19/2. Elsevier/Spektrum, Heidelberg

Kuiper-Goodman T, Falconer I, Fitzgerald J (1999) Human health aspects. In: Toxic cyanobacteria in water: a guide to their public health consequences, monitoring and management. E \& F Spon, London, p 113-153

$>$ Lawton L, Codd G (1991) Cyanobacterial (blue-green algal) toxins and their significance in UK and European waters. Water Environ J 5:460-465

Leland HV, Porter SD (2000) Distribution of benthic algae in the upper Illinois River basin in relation to geology and land use. Freshw Biol 44:279-301

McGregor G (2007) Freshwater Cyanoprokaryota of NorthEastern Australia. 1. Oscillatoriales. Australian Biological Resources Study, Canberra

Méjean A, Mann S, Maldiney T, Vassiliadis G, Lequin O, Ploux O (2010) Evidence that biosynthesis of the neurotoxic alkaloids anatoxin-a and homoanatoxin-a in the cyanobacterium Oscillatoria PCC 6506 occurs on a modular polyketide synthase initiated by l-proline. J Am Chem Soc 131:7512-7513

Mez K, Beattie K, Codd G, Hanselmann K, Hauser B, Naegeli $\mathrm{H}$, Preisig $\mathrm{H}$ (1997) Identification of a microcystin in benthic cyanobacteria linked to cattle deaths on alpine pastures in Switzerland. Eur J Phycol 32:111-117

Milne JR, Watts LF (2006) Toxic benthic cyanobacteria proliferations in Wellington's rivers in 2005/06. Greater Wellington Regional Council, Wellington

Negri AP, Jones GJ, Hindmarsh M (1995) Sheep mortality associated with paralytic shellfish poisons from the cyanobacterium Anabaena circinalis. Toxicon 33: 1321-1329

Oliver RL, Gnaf GG (2000) Freshwater blooms. In: Whitton BA, Potts M (eds) The ecology of cyanobacteria. Kluwer Academic, Dordrecht, p 149-194

Paerl HW (1996) A comparison of cyanobacterial bloom dynamics in freshwater, estuarine and marine environments. Phycologia 35:25-35

Editorial responsibility: Rutger de Wit, Montpellier, France
Pankratova EM, Borodina NV, Reznik EN (1998) Nitrogen fixation by the nonheterocyctous cyanobacterium Phormidium inundatum. Microbiology 67:625-631

Perrie A (2007) The state of water quality in selected rivers and streams in the Wellington region, 2003-2006. Greater Wellington Regional Council, Wellington

- Rapala J, Sivonen K (1998) Assessment of environmental conditions that favor hepatotoxic and neurotoxic Anabaena spp. strains cultured under light limitation at different temperatures. Microb Ecol 36:181-192

> Rapala J, Sivonen K, Luukkainen R, Niemela SI (1993) Anatoxin-a concentration in Anabaena and Aphanizomenon under different environmental conditions and comparison of growth by toxic and non toxic Anabaena-strains - a laboratory study. J Appl Phycol 5:581-591

Robarts RD, Zohary $\mathrm{T}(1987)$ Temperature effects on the photosyntheic capacity, respiration, and growth rates of bloom-forming cyanobacteria. NZ J Mar Freshw Res 21: 391-399

Saker ML, Thomas AD, Norton JH (1999) Cattle mortality attributed to the toxic cyanobacterium Cylindrospermopsis raciborskii in an outback region of North Queensland. Environ Toxicol 14:179-182

Seifert M, McGregor G, Eaglesham G, Wickramasinghe W, Shaw G (2007) First evidence for the production of cylindrospermopsin and deoxy-cylindrospermopsin by the freshwater benthic cyanobacterium, Lyngbya wollei (Farlow ex Gomont) Speziale and Dyck. Harmful Algae 6:73-80

Sivonen K, Jones G (1999) Cyanobacteria toxins. In: Chorus I, Bartrum J (eds) Toxic cyanobacteria in water: a guide to their public health consequenes, monitoring and management. E \& P Spon, London, p 41-111

Smith RA, Lewis D (1987) A rapid analysis of water for anatoxin-a. The unstable toxic alkaloid from Anabaena flos-aquae, the stable non-toxic alkaloids left after bioreduction and a related amine which may be nature's precursor to anatoxin-a. Vet Hum Toxicol 29:153-154

Song L, Sano T, Li R, Watanabe MM, Liu Y, Kaya K (1998) Microcystin production of Microcystis viridis (cyanobacteria) under different culture conditions. Phycol Res 46:19-23

Thacker RW, Paul VJ (2001) Are benthic cyanobacteria indicators of nutrient enrichment? Relationships between cyanobacterial abundance and environmental factors on the reef flats of Guam. Bull Mar Sci 69:497-508

Vilalta E, Guasch H, Muñoz I, Navarro E and others (2003) Ecological factors that co-occur with geosmin production by benthic cyanobacteria. The case of the Llobregat River. Arch Hydrobiol Algoll Stud109:579-592

Wood SA, Selwood AI, Rueckert A, Holland PT and others (2007) First report of homoanatoxin-a and associated dog neurotoxicosis in New Zealand. Toxicon 50:292-301

Wood SA, Hamilton DP, Paul WJ, Safi KA, Williamson WM (2009) New Zealand guidelines for managing cyanobacteria in recreational fresh waters. Ministry for the Environment and Ministry of Health, Wellington.

> Wood SA, Heath MW, McGregor G, Holland PT, Munday R, Ryan KG (2010) Identification of a benthic microcystinproducing filamentous cyanobacterium (Oscillatoriales) associated with a dog poisoning in New Zealand. Toxicon 55:897-903

Submitted: October 18, 2010; Accepted: April 26, 2011

Proofs received from author(s): July 6, 2011 